\title{
Fabrication of In(III)-alizarin red S complex trap for efficient detection of fluoride ion in aqueous environs
}

Pritam Singh ${ }^{1}$ and Nabanita Naskar ${ }^{2^{*}}$

\begin{abstract}
The work discusses about the synthesis of indium-alizarin red S complex followed by its application toward the sensing of $\mathrm{F}^{-}$ion. At first, the interaction between indium and alizarin red $\mathrm{S}$ dye was studied at three different $\mathrm{pH}$ medium, $\mathrm{pH}$ 4, 7 and 9, of which pH 7 gave the best result. The indium-alizarin red S complex so obtained was then utilized for the ratiometric sensing of fluoride ion using absorption spectroscopy with variation of temperature. The lowest limit of detection $(0.040 \mathrm{mM})$ was obtained at $313 \mathrm{~K}$. The mechanism for the sensing of $\mathrm{F}^{-}$ion was then investigated using isothermal titration calorimetry. The endothermic nature of the interaction between $\mathrm{F}^{-}$ion with indium-alizarin red $\mathrm{S}$ complex shows temperature dependence on the sensing experiment. At the end, the utility of the technique toward natural sample was also examined. The present work reports a simple, rapid and efficient detection of fluoride anion in environmental water samples.
\end{abstract}

Keywords: Indium-alizarin red S complex, Fluoride anion, Sensing, Temperature dependence, Environmental water samples

\section{Introduction}

Alizarin red S or ARS (1,2-dihydroxy-9,10-anthraquinone-3-sulfonic acid), a well-known complexing agent for the analytical determination of metal ions, is a water soluble sulfonic acid derivative of alizarin (1,2-dihydroxy9,10-anthraquinone) (Fain et al. 2004). ARS can form two types of complexes with the metal ions, viz., monometallic (red color) and bimetallic (blue color) (Fain et al. 2004). On the other hand, Indium is a group 13 element that can form organometallic compounds with ligands such as $-\mathrm{Me}_{3}$, several aryl, alkyl, and allyl groups, which are mainly used for organic transformations (Shen et al. 2013). In can form 1:1 coordination complex with ARS (Biver et al. 2018) and this complex is used for detection of In(III) in trace amount (Zhang et al. 2015). In the

\footnotetext{
*Correspondence: g.nabanitanaskar94@gmail.com

${ }^{2}$ Saha Institute of Nuclear Physics, 1/AF, Bidhannagar, Kolkata 700064, India

Full list of author information is available at the end of the article
}

present study, we have attempted to use In-ARS complex for sensing of fluoride ion. There are several literature reports based on metal-ARS complex that can be used for such application (Sathish et al. 2007; Xu et al. 2004; Cardwell et al. 1988; Yasuda and Lambert 1958).

Fluoride is present in our bone and teeth. The common sources of fluoride ion are soil, groundwater, plants, rocks, etc. At low concentration, this ion is beneficial to our teeth and is required to make it strong, to decrease the growth of oral bacteria and to avoid other dental ailments (Fawell et al. 2006). However, excess of fluoride causes several side effects including teeth fluorosis (Bishop and Sansoucy 1978), skeletal fluorosis (Agarwal et al. 2003), etc. The prescribed permissible limit of $\mathrm{F}^{-}$ion in drinking water is $1.5 \mathrm{mg} \mathrm{L}^{-1}(0.08 \mathrm{mM})$ as suggested by the World Health Organization (WHO 2004) and Bureau of Indian Standard (BIS 2012). At the same time, the $\mathrm{F}^{-}$concentration below $0.5 \mathrm{mg} \mathrm{L}^{-1}$ generates adverse health hazards like bone deformation, problem with dental enamel, etc. (Jha et al. 2013). The maximum limit is 
also only a rough estimation as a survey in China suggested that $40 \%$ of Chinese suffered from dental fluorosis even at $1 \mathrm{mg} \mathrm{L}^{-1}$ concentration of $\mathrm{F}^{-}$(WHO 1996). High concentration of $\mathrm{F}^{-}$has also been reported from India, which is often beyond the permissible limit in groundwater (Choubisa et al. 2001; Ali et al. 2019). As we generally intake this halide ion from the environment via groundwater, it is important to monitor the concentration of the same.

There are plenty of $\mathrm{F}^{-}$detection techniques reported in the literature, some of which have been discussed here briefly. Barnett and coworkers had developed a method for spectroscopic detection of $\mathrm{F}^{-}$using zirconyl xylenol orange as a spectroscopic reagent. The limit of detection of this procedure was as low as $0.05 \mu \mathrm{g} \mathrm{mL}^{-1}$ with the linear calibration up to $10 \mu \mathrm{g} \mathrm{mL}^{-1}$ (Barnett et al. 1993). In another report by Barghouthi and Amereih (2012, 2017), spectrophotometric determination of $\mathrm{F}^{-}$ was carried out in drinking water using Al-triphenylmethane complex. Two dyes, chrome azurol B and malachite green were used as complexing agent for $\mathrm{Al}$ and the resulting complex could sense $\mathrm{F}^{-}$ion with the detection limit $0.2 \mathrm{mg} \mathrm{L}^{-1}$ and $0.1 \mathrm{mg} \mathrm{L}^{-1}$ for chrome azurol $\mathrm{B}$ and malachite green, respectively (Barghouthi and Amereih 2012). Jiao et al. (2015) has elaborately reviewed fluorimetric detection of $\mathrm{F}^{-}$in cellular environment using some fluorescent fluoride probes like anthracene, cyanine, coumarine, rhodamine, etc., with the help of different photophysical process that included fluorescence resonance energy transfer, intramolecular charge transfer, photoinduced electron transfer mechanism, etc. In another review by Zhou et al. (2014), a variety of Lewis acids, polymer moiety, quantum dots, mesoporous materials, organic molecule containing ring structures such as indole and pyrrole has been mentioned for fluorimetric and colorimetric determination of $\mathrm{F}^{-}$(Zhou et al. 2014). Apart from these, there are also some reports present in the literature based on the alizarin, alizarin red $\mathrm{S}$, its derivative or its metal-based complex, which can be used for the detection of $\mathrm{F}^{-}$anion. Table 1 tabulates few sensing methods developed with alizarin along with their limit of detection.

Table 1 shows that alizarin is capable of complex formation with metals and in turn can be used for fluoride sensing. Hence, we opted for synthesis of In-ARS complex and observed its applicability toward detection of $\mathrm{F}^{-}$in trace quantity in aqueous medium. The complexation process was studied using absorption spectroscopy at three different $\mathrm{pH}$. The sensing was carried out using absorption spectroscopy and found to be effective upon variation in temperature. The sensing mechanism was studied using Isothermal Titration Calorimetry (ITC) technique. Studies related to interference from different halides, $\mathrm{SCN}^{-}, \mathrm{ClO}_{4}{ }^{-}, \mathrm{NO}_{2}{ }^{-}$and $\mathrm{N}_{3}{ }^{-}$ions were carried out. Interferences from cations like $\mathrm{K}^{+}, \mathrm{Mg}^{2+}, \mathrm{Ca}^{2+}$,

Table 1 Few reports related to $\mathrm{F}^{-}$sensing using alizarin, alizarin red S, its derivative, etc.

\begin{tabular}{|c|c|c|c|c|}
\hline Sensor & Sensing method & $\begin{array}{l}\text { Limit of } \\
\text { detection } \\
\text { (LOD) (mM) }\end{array}$ & Detection Range (mM) & References \\
\hline $\begin{array}{l}\text { 1,2-dihydroxyanthra-quinone } \\
\text { (alizarin) }\end{array}$ & Fluorimetric method & Trace level & $0-0.084$ & Hirai and François (2014) \\
\hline Aluminum quinalizarin complex & Spectrophotometric method & 0.005 & $0-0.105$ & Barghouthi and Amereih (2017) \\
\hline $\mathrm{Al}(\mathrm{III})$-alizarin red S complex & $\begin{array}{l}\text { Absorption and emission spectro- } \\
\text { scopic method }\end{array}$ & 0.005 & $0.005-0.3$ & Sathish et al. (2007) \\
\hline Zr(IV)-Alizarin red S complex & Absorption spectroscopic method & 0.003 & $0.005-0.526$ & Cardwell et al. (1988) \\
\hline Cerium-alizarin complexone & Colorimetric method & - & $0.037-0.063$ & Sen et al. (1998) \\
\hline La(III)-alizarin fluorine blue complex & Spectrophotometric method & 0.004 & $0.010-0.063$ & Leon-Gonzalez et al. (1985) \\
\hline Thorium-alizarin red S chelate & Spectrophotometric method & - & $0-0.789$ & Yasuda and Lambert (1958) \\
\hline $\mathrm{La}^{3+}$-alizarin complexone & Reverse phase HPLC & $2 \times 10^{-4}$ & $5 \times 10^{-5}$ to 0.008 & Xu et al. (2004) \\
\hline $\begin{array}{l}\text { Alizarin-o-aminomethylphenyl- } \\
\text { boronic acid }\end{array}$ & Fluorescence spectroscopy & - & - & Kubo et al. (2006) \\
\hline $\begin{array}{l}\text { La(III)-alizarin fluorine blue S com- } \\
\text { plex }\end{array}$ & Spectrophotometric method & - & $0-0.013$ & Leonard and Murray (1974) \\
\hline Ce(III)-alizarin complexone & Electrochemical method & $9 \times 10^{-4}$ & $8 \times 10^{-5}$ to $5 \times 10^{-3}$ & Guanghan et al. (1991) \\
\hline La-alizarin complexone & ICP-OES & $6 \times 10^{-4}$ & $0-0.003$ & Miyazaki and Bansho (1987) \\
\hline La(III)-alizarin complexone & Voltammetric method & - & $4.8 \times 10^{-6}$ to $1 \times 10^{-4}$ & Jin et al. (1990) \\
\hline $\begin{array}{l}\text { Alizarin complexone/layered double } \\
\text { hydroxide ultrathin film }\end{array}$ & Colorimetric method & 0.012 & $0.003-0.024$ & Jia et al. (2013) \\
\hline
\end{tabular}


$\mathrm{Cr}^{2+}, \mathrm{Mn}^{2+}, \mathrm{Fe}^{3+}, \mathrm{Co}^{2+}, \mathrm{Ni}^{2+}, \mathrm{Cu}^{2+}, \mathrm{Zn}^{2+}$ were also investigated.

\section{Experimental}

\section{Materials and reagents}

Alizarin Red S (ARS) was purchased from Nice Chemicals Pvt. Ltd. NIST Standard Indium nitrate $\left(\operatorname{In}\left(\mathrm{NO}_{3}\right)_{3}\right)$ (3124a) was used in the experiment. Sodium fluoride $(\mathrm{NaF})(99 \%)$, potassium chloride $(\mathrm{KCl})(99.5 \%)$, potassium bromide $(\mathrm{KBr})(99 \%)$, potassium iodide (KI) (99\%), potassium perchlorate $\left(\mathrm{KClO}_{4}\right)(99.5 \%)$ and ammonium thiocyanate $\left(\mathrm{NH}_{4} \mathrm{SCN}\right)$ were obtained from Merck, India. Sodium Azide $\left(\mathrm{NaN}_{3}\right)(\geq 99.99 \%)$ and sodium nitrite $\left(\mathrm{NaNO}_{2}\right)(\geq 97 \%)$ were obtained from SigmaAldrich, USA. pH adjustment was done using hydrochloric acid $(\mathrm{HCl})(35 \%)$ and sodium hydroxide $(\mathrm{NaOH})$ $(\geq 97 \%)$, which were obtained from Merck, India. Deionized water $(18.3 \mathrm{M} \Omega \mathrm{cm})$ was used throughout the experiment. All other reagents were of AR grade.

\section{Instrument used}

Absorption data were obtained using Jasco UV 650 Spectrophotometer. A Mettler Toledo digital balance (corrected up to fifth decimal place) was used for measuring the weights. The temperature controlled sensing experiment for $\mathrm{F}^{-}$ion was carried out using JASCO UV-650 spectrophotometer connected with a Peltier system. Thermodynamic parameters to understand the interaction between ARS, In and fluoride ion were determined using Isothermal Titration Calorimetry (ITC model: VP-ITC, make: Malvern Instruments UK). Titration data analysis was done using Microcal LLC ITC software.

\section{In-ARS complexation}

The complexation was studied at three different $\mathrm{pH}$ (viz, $\mathrm{pH} \mathrm{4,} 7$ and 9). Buffer solution was not used, as it was not favorable for the complexation process and reduced the sensitivity. $1.6 \mathrm{~mL}$ of $\mathrm{pH}$ adjusted solution was treated with $0.4 \mathrm{~mL} 0.1 \mathrm{mM}$ of ARS solution. Then, it was treated with measured aliquots of In solution of $1 \mathrm{mM}(0.005 \mathrm{~mL}$ each time). The complexation was studied using absorption spectroscopy.

\section{Absorption spectroscopy}

The interaction between In and ARS was studied using absorption spectroscopy at three different $\mathrm{pH}$ solution. Different $\mathrm{pH}$ solutions ( $\mathrm{pH} \mathrm{4,7}$ and 9) were prepared using dilute $\mathrm{HCl}$ or $\mathrm{NaOH}$ solution in order to obtain the best condition for complexation between In and ARS. ARS has its characteristic absorption maxima at $\sim 422 \mathrm{~nm}$ in $\mathrm{pH} 4$ and $\mathrm{pH} 7$ medium and at $516 \mathrm{~nm}$ in $\mathrm{pH} 9$ medium. $0.4 \mathrm{~mL}$ of $0.1 \mathrm{mM}$ of ARS was taken in $1.6 \mathrm{~mL}$ of $\mathrm{pH}$ adjusted solution in a quartz cuvette and then treated with a measured aliquots $(0.005 \mathrm{~mL})$ of $1 \mathrm{mM}$ of $\operatorname{In}\left(\mathrm{NO}_{3}\right)_{3}$ solution. The sensing study was also carried out using absorption spectroscopy using a pre-prepared In-ARS complex, and then, the complex was treated with small aliquots $(0.002 \mathrm{~mL})$ of $1 \mathrm{mM}$ of $\mathrm{F}^{-}$solution. Interference from halogens (viz., $\mathrm{Cl}^{-}$, $\mathrm{Br}^{-}$and $\mathrm{I}^{-}$), other anions (viz., $\mathrm{SCN}^{-}, \mathrm{ClO}_{4}^{-}, \mathrm{NO}_{2}^{-}$, $\mathrm{N}_{3}^{-}$) and cations $\left(\mathrm{K}^{+}, \mathrm{Mg}^{2+}, \mathrm{Ca}^{2+}, \mathrm{Cr}^{2+}, \mathrm{Mn}^{2+}, \mathrm{Fe}^{3+}\right.$, $\mathrm{Co}^{2+}, \mathrm{Ni}^{2+}, \mathrm{Cu}^{2+}, \mathrm{Zn}^{2+}$ ) were studied using absorption spectroscopy.

\section{Sensing of $\mathrm{F}^{-}$ion}

As the complexation between In and ARS was found to be most effective at $\mathrm{pH} 7$, the sensing of $\mathrm{F}^{-}$ion was carried out with the In-ARS complexation in $\mathrm{pH} 7$ media. In order to check the effect of temperature, the sensing study was carried out at three different temperatures of $283 \mathrm{~K}, 298 \mathrm{~K}$ and $313 \mathrm{~K} .1 .6 \mathrm{~mL}$ of pH 7 adjusted solution was treated with $0.4 \mathrm{~mL}$ of $0.1 \mathrm{mM}$ ARS and $0.04 \mathrm{~mL}$ of $1 \mathrm{mM}$ of In solution. Then, this solution was treated with measured aliquots $(0.002 \mathrm{~mL})$ of $\mathrm{F}^{-}$solution and observed using absorption spectroscopy.

\section{ITC analysis}

The interaction between In with ARS and In-ARS complex with $\mathrm{F}^{-}$ion was studied using this technique. The thermodynamic parameters like $\Delta H$ (change in enthalpy), $\Delta S$ (change in entropy) and other parameters like the association constant $\left(K_{\mathrm{a}}\right)$ and stoichiometry for the interaction between two or more substances can be obtained from this analysis (Srivastava et al. 2020). The instrumentation consists of two cells, viz. sample cell and reference cell enclosed in a jacket. For the interaction between In and ARS, the sample cell contains $1 \mathrm{mM}$ of ARS and the reference cell contains $10 \mathrm{mM}$ of In solution. Deionized water of $\mathrm{pH} 7$ was taken as blank during the experiment. $2 \mathrm{~mL}$ of $1 \mathrm{mM}$ ARS was treated with $10 \mathrm{mM}$ of In solution with 56 injections ( $5 \mu \mathrm{L}$ each). The temperature during this experiment was maintained at $298 \mathrm{~K}$ while the duration of the experiment was $169 \mathrm{~min}$. In a similar manner, for the interaction between In-ARS complex and $\mathrm{F}^{-}$, the sample cell contains $1 \mathrm{mM}$ In and $1 \mathrm{mM}$ ARS mixture (1:1 molar ratio) and the reference cell contains $10 \mathrm{mM}$ of NaF. Deionized water of $\mathrm{pH} 7$ was taken as blank during this experiment. $2 \mathrm{~mL}$ of In-ARS mixture (1:1 molar ratio) was then treated with $10 \mathrm{mM}$ of $\mathrm{NaF}$ solution with 57 injections ( $5 \mu \mathrm{L}$ each). This experiment was analyzed for $172 \mathrm{~min}$ at $313 \mathrm{~K}$ of temperature.

The change in Gibbs free energy value $(\Delta G)$ for the interaction between the interactive moieties can also be 
calculated from the value of $\Delta H$ and $\Delta S$, knowing the value of temperature $(T)$ in Kelvin scale with the help of following equation (Eq. 1)

$$
\Delta G=\Delta H-T \Delta S .
$$

The value of $\Delta G$ can also be obtained from the value of association constant $\left(K_{\mathrm{a}}\right)$ with the help of following equation (Eq. 2)

$$
\Delta G=-R T \ln K_{\mathrm{a}}
$$

where $R$ is the universal gas constant.

\section{Interference study}

The interferences in the $\mathrm{F}^{-}$detection from different anions like $\mathrm{Cl}^{-}, \mathrm{Br}^{-}, \mathrm{I}^{-}, \mathrm{SCN}^{-}, \mathrm{ClO}_{4}{ }^{-}, \mathrm{NO}_{2}{ }^{-}, \mathrm{N}_{3}{ }^{-}$and cations like $\mathrm{K}^{+}, \mathrm{Mg}^{2+}, \mathrm{Ca}^{2+}, \mathrm{Cr}^{2+}, \mathrm{Mn}^{2+}, \mathrm{Fe}^{3+}, \mathrm{Co}^{2+}, \mathrm{Ni}^{2+}$, $\mathrm{Cu}^{2+}, \mathrm{Zn}^{2+}$ were studied at $313 \mathrm{~K}$. In order to study the interference, aliquots of $10 \mathrm{mM}$ each of the interfering ions were added to In-ARS mixture and then this solution was treated with $10 \mathrm{mM} \mathrm{F}^{-}$aliquot in order to keep same concentration $(0.1 \mathrm{mM})$ of the interfering ion to that of $\mathrm{F}^{-}$ion. The results were studied using absorption spectroscopy. The absorption data in presence of only $\mathrm{F}^{-}$ ion were then compared with that of the absorption data in presence of both the interfering ions and $\mathrm{F}^{-}$ion.

\section{Analysis of natural samples}

Analysis of natural sample was done at $313 \mathrm{~K}$ to check the practicability of this method toward the environmental samples. Natural water samples were obtained from different locations, out of which five were riverine samples (S1, S2, S3, S4, S5) and two groundwater (tubewell) samples. Three riverine water samples (S1, S2, S3) were collected from three different ports/harbors of coastal West Bengal. Indian Sundarbans is the world's largest mangrove land, consisting of numerous Islands and interconnected river-ways (Chaudhuri et al. 2017; Naskar et al. 2020). Human settlements usually communicate in these Islands through small boats, semi-mechanized boats, etc. Small sized, mechanized trawlers are used for fishing purposes in these estuarine coastal belts. The surfaces of boats and ships are often coated with antifouling agents to avoid corrosion and aging/damaging of surface-equipment. Among several antifouling agents, fluorine-containing polymers or composites are often used as surface-coating due to its considerable antifouling performance (Gu et al. 2020). Small jetties and launch-yards are common in Sundarbans, where boats, ships, mechanized trawlers, etc., are kept, repaired and also used for passenger transport. One of the groundwater samples (S6) were collected from Arambagh Hatcharies Ltd., Shunmuni, West Bengal and the other from a school tubewell (S7), Nabakishar Vidyalaya, Tantipara,
Birbhum district, West Bengal. Birbhum district is one of the several fluoride contaminated areas in West Bengal, India. Coordinates of each samples have been provided later. Samples were collected in clean plastic containers, and they were parafilm wrapped and preserved for further experimentation. Later, for the analysis, $1.6 \mathrm{~mL}$ of $\mathrm{pH} 7$ adjusted aqueous medium was treated with $0.4 \mathrm{~mL}$ of $0.1 \mathrm{mM}$ ARS and $0.04 \mathrm{~mL} 1 \mathrm{mM}$ In. This In-ARS complex was then treated with $0.05 \mathrm{~mL}$ of natural samples, and the results were analyzed.

\section{Results and discussion}

\section{Absorption spectroscopy}

Absorption spectroscopy revealed that the best $\mathrm{pH}$ condition for complexation between In and ARS was $\mathrm{pH} 7$. For $\mathrm{pH} 4$ and $\mathrm{pH} 7$ medium, upon addition of In in $\mathrm{pH}$ adjusted ARS solution, the absorption corresponding to $\lambda_{\max }$ of ARS $(\sim 422 \mathrm{~nm})$ decreased gradually suggesting the steady decline of free ARS molecules and simultaneously the absorption at $\lambda=\sim 522 \mathrm{~nm}$ increased due to the gradual formation of In-ARS complex (Additional file 1: Fig. S1 and Fig. 1, respectively). Isosbestic point was observed at $\sim 462 \mathrm{~nm}$. The stoichiometry and association constant for the interaction between In and ARS were studied using Benesi-Hildebrand (B-H) equation (Eq. 3)

$$
\frac{1}{A-A_{0}}=\frac{1}{A_{1}-A_{0}}+\frac{1}{\left(A_{1}-A_{0}\right) K_{\mathrm{a}}[\mathrm{M}]}
$$

where $A_{0}=$ the absorbance of ARS solution in absence of In; $A_{1}=$ absorbance of ARS when it is completely bound with In; $A=$ absorbance of ARS with gradual addition of In; $[\mathrm{M}]=$ concentration of In; $K_{a}=$ binding/association constant (Ghatak et al. 2013).

The stoichiometry for the In-ARS complexation was found to be 1:1 and the highest association constant

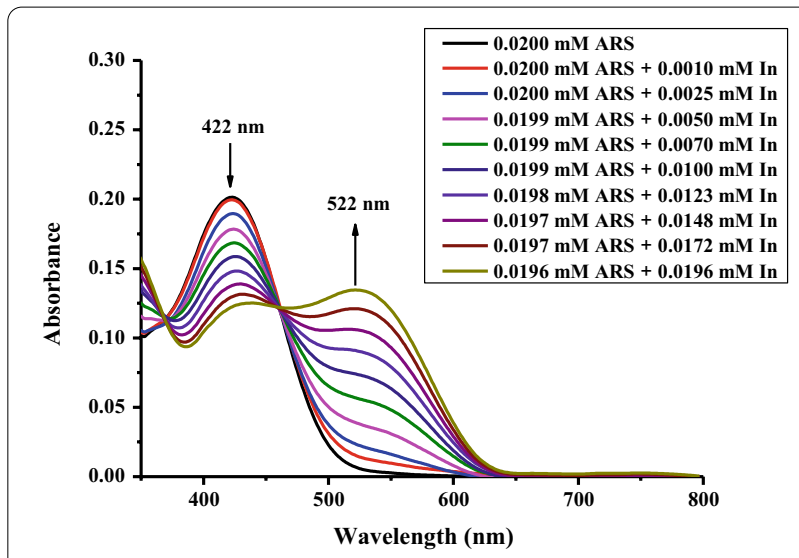

Fig. 1 Interaction between In and ARS at pH 7 medium 


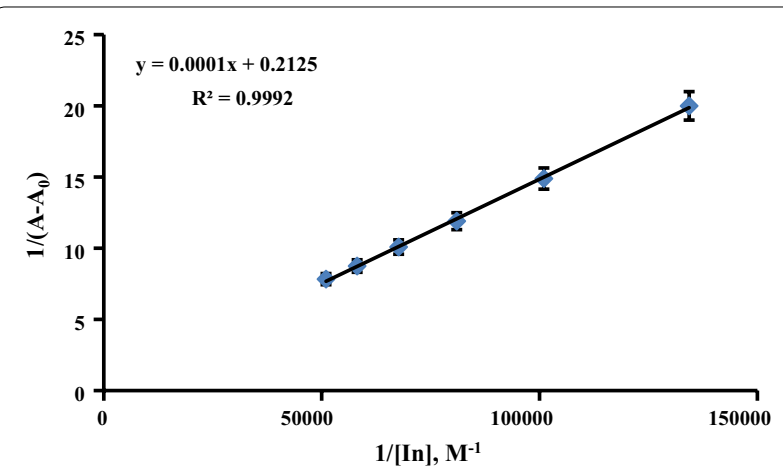

Fig. 2 B-H Plot for the interaction between $\mathrm{In}$ and ARS at $\mathrm{pH} 7$

$\left(K_{\mathrm{a}}=2.12 \times 10^{3} \mathrm{M}^{-1}\right)$ was obtained at $\mathrm{pH} 7$ as reflected from the $\mathrm{B}-\mathrm{H}$ plot (Fig. 2). Therefore, $\mathrm{pH} 7$ was considered as the best condition for the In-ARS complexation. At $\mathrm{pH} 4$, the intercept value was negative so the association constant could not be measured (Additional file 1: Fig. S2), whereas at $\mathrm{pH}$ 9, the situation was different. The characteristic absorption maximum of ARS in $\mathrm{pH} 9$ media was obtained at $516 \mathrm{~nm}$. Upon addition of indium solution to this $\mathrm{pH}$ adjusted solution, a new peak at $427 \mathrm{~nm}$ was observed (Additional file 1: Fig. S3). But the change of absorbance at $516 \mathrm{~nm}$ and $427 \mathrm{~nm}$ did not give a regular pattern, so the corresponding $\mathrm{B}-\mathrm{H}$ plot was not constructed. We studied the interaction between In and ARS in presence of $\mathrm{pH} 4$ and $\mathrm{pH} 9$ buffer medium, which has been provided as supplementary figures (Additional file 1: Figs. S4 and S5). The results were not suitable as compared to results obtained without buffer medium.

\section{Sensing of $\mathrm{F}^{-}$ion in aqueous solution}

The main idea behind sensing is that In can form 1.67 complex with the $\mathrm{F}^{-}$ion $\left(\mathrm{InF}_{1.67}\right)$ (as indicated by ITC experiment discussed later). If the association constant and the enthalpy of formation of $\mathrm{InF}_{1.67}$ is higher than that of In-ARS complex (1:1), then the In-ARS complex will break down in presence of $\mathrm{F}^{-}$causing generation of free ARS and $\mathrm{InF}_{1.67}$ molecules. The mechanism has been discussed elaborately in the next section. Also, the results thus analyzed by absorption spectroscopy suggested the same observation as discussed here.

In presence of trace amount of $\mathrm{F}^{-}$, the In-ARS complexation was broken down, decreasing the absorbance at $\lambda=\sim 522 \mathrm{~nm}$ and generation of free ARS as indicated by increased absorbance at $\lambda=\sim 422 \mathrm{~nm}$ with the isosbestic point at $\sim 462 \mathrm{~nm}$ (Fig. 3). The ratio of absorbance at $\lambda=\sim 522 \mathrm{~nm}$ to absorbance at $\lambda=\sim 422 \mathrm{~nm}$ gave a linear relationship with respect to the concentration of $\mathrm{F}^{-}$ion (Fig. 4). From this calibration plot, parameters

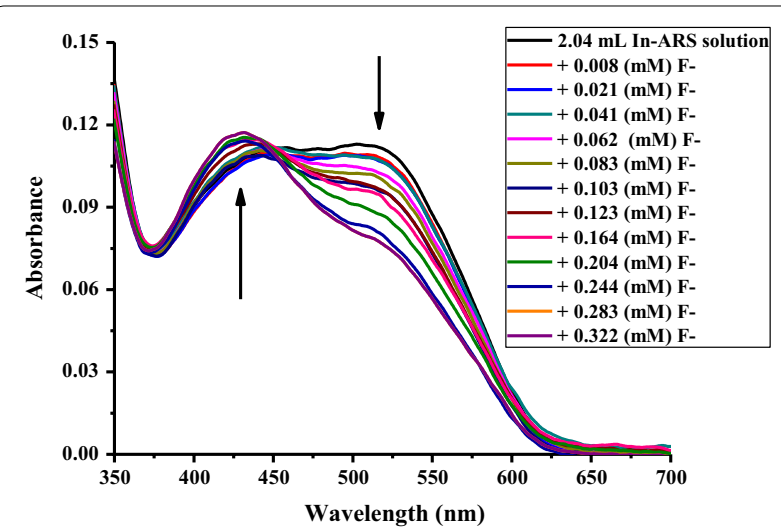

Fig.3 Absorption spectral change for the sensing of $\mathrm{F}^{-}$at $313 \mathrm{~K}$

such as standard deviation, limit of detection (LOD), and limit of quantification (LOQ) were obtained (Table 2). The sensing experiment was carried out at three different temperatures (283, 298 and $313 \mathrm{~K})$ to see the effect of temperature on this sensing mechanism. The calibration plot for sensing of $\mathrm{F}^{-}$at $283 \mathrm{~K}$ and $298 \mathrm{~K}$ has been presented in Additional file 1: Figs. S6 and S7, respectively. The results thus obtained from Table 2 suggested that the lowest LOD was obtained at $313 \mathrm{~K}$. Hence, the sensing process was carried out at this temperature using ITC method.

\section{Sensing mechanism and ITC analysis}

The sensing mechanism was studied using Isothermal Titration Calorimetry (ITC) experiment to get a clear picture about the thermodynamic parameters for the interaction between ARS with In and $\mathrm{F}^{-}$with In-ARS complex.

The complexation between In and ARS has been studied at $298 \mathrm{~K}$ and $\mathrm{pH} 7$. Results obtained suggested that the association between In and ARS is 1:1.15 $( \pm 0.08)$ with association constant $\left(\mathrm{K}_{\mathrm{a}}\right)$ equal to $1.22 \times 10^{3}$ $( \pm 209) \mathrm{M}^{-1}$ (Fig. 5), which are in good agreement with the B-H plot obtained from the absorption data. The

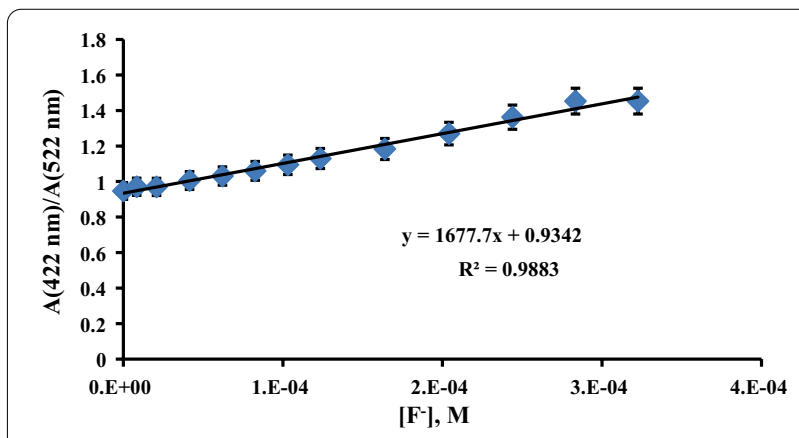

Fig.4 Calibration plot for the sensing of $\mathrm{F}^{-}$at $313 \mathrm{~K}$ 
Table 2 Different analytical parameters for the detection of $\mathrm{F}^{-}$ion at different temperature

\begin{tabular}{llll}
\hline Parameter $(\mathbf{s})$ & \multicolumn{3}{l}{ Temperature (K) } \\
\cline { 2 - 4 } & $\mathbf{2 8 3}$ & $\mathbf{2 9 8}$ & $\mathbf{3 1 3}$ \\
\hline Regression equation & $Y=s X+C$ & $Y=s X+C$ & $Y=s X+C$ \\
Slope $(s)\left(\mathrm{mmol}^{-1}\right)$ & 2.600 & 2.505 & 1.677 \\
Intercept $(C)$ & 0.983 & 0.850 & 0.934 \\
Correlation coefficient $\left(R^{2}\right)$ & 0.907 & 0.983 & 0.988 \\
Standard deviation $(\sigma)$ & 0.098 & 0.055 & 0.020 \\
Limit of detection $(L O D)=3.3 \times \sigma / s)(\mathrm{mM})$ & 0.124 & 0.072 & 0.040 \\
Limit of quantification $(\mathrm{LOQ})=10 \times \sigma / \mathrm{s})(\mathrm{mM})$ & 0.377 & 0.219 & 0.122 \\
Linear range $(\mathrm{mM})$ & $0.008-0.041$ & $0.018-0.253$ & $0.008-0.244$ \\
\hline
\end{tabular}

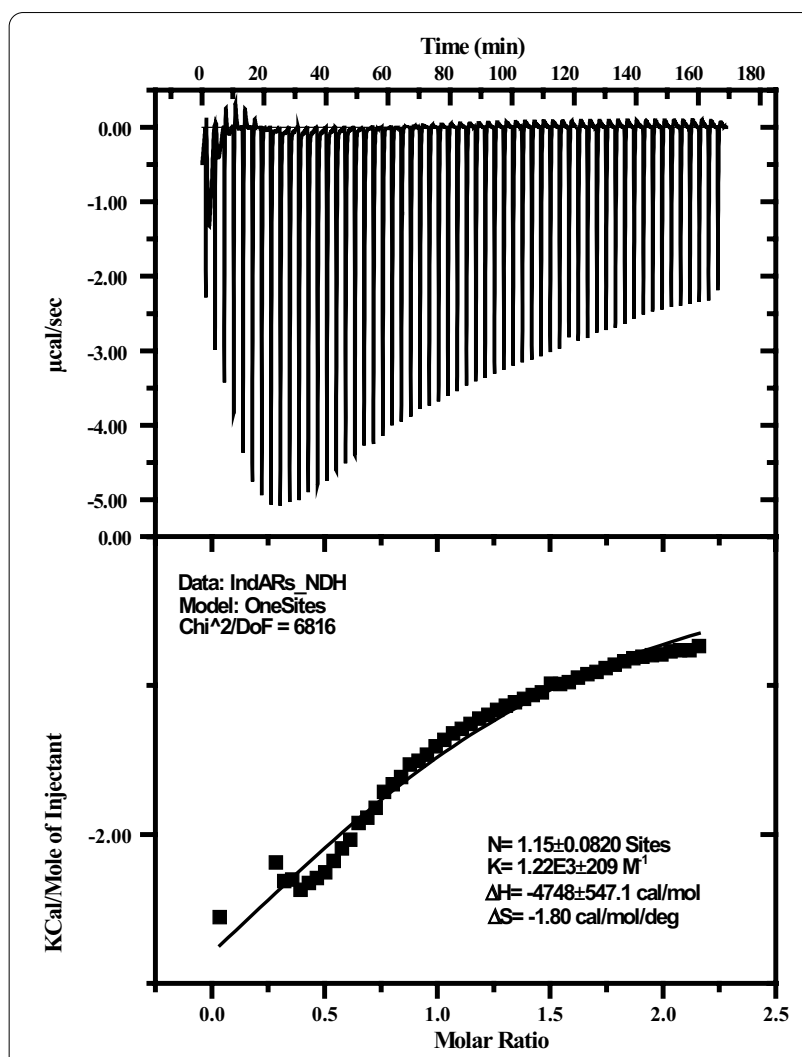

Fig. 5 ITC data for binding isotherm for interaction between In and ARS at $298 \mathrm{~K}$ (normalization was done with heats per peak as a function of molar ratio in the calorimetric cell) change in enthalpy $(\Delta \mathrm{H})$ and change in entropy $(\Delta \mathrm{S})$ associated with this complexation are $-4748( \pm 547.1)$ $\mathrm{cal} / \mathrm{mol}$ and $-1.80 \mathrm{cal} / \mathrm{mol} / \mathrm{deg}$. Hence, the change in Gibbs free energy $(\Delta G)$ associated with the complexation can be obtained from two mathematical relationships Eqs. 1 and 2. From Eq. (1), the $\Delta \mathrm{G}$ value is equal to $-4211.42 \mathrm{cal} / \mathrm{mol}$ and from Eq. (2), the $\Delta \mathrm{G}$ value is equal to $-4192.14 \mathrm{cal} / \mathrm{mol}$.

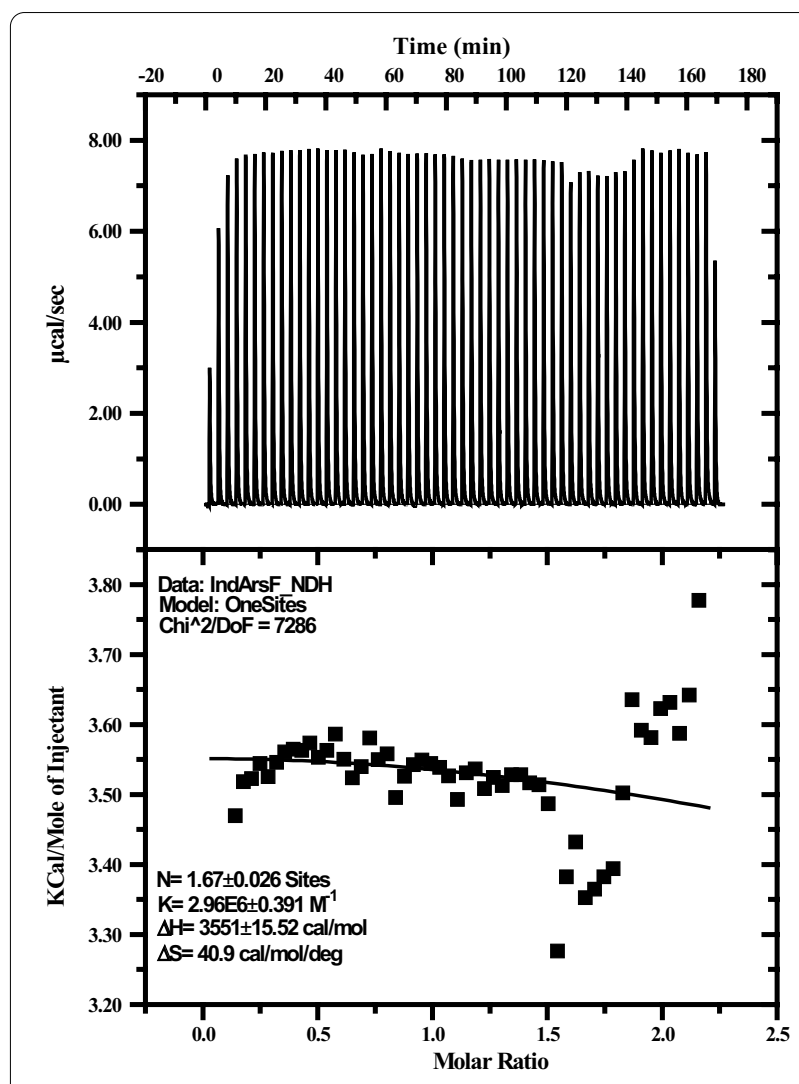

Fig. 6 ITC data for binding isotherm for interaction between In-ARS complex and $\mathrm{F}^{-}$at $313 \mathrm{~K}$ (normalization was done with heats per peak as a function of molar ratio in the calorimetric cell)

The interaction between $\mathrm{F}^{-}$and In-ARS complex was studied using ITC instrument at $313 \mathrm{~K}$ (Fig. 6) as the LOD for sensing of $\mathrm{F}^{-}$is lowest at this temperature. Results obtained suggested that the complexation between Indium and $\mathrm{F}^{-}$was obtained in the ratio of 1:1.67 $( \pm 0.026)$ with association constant equal to $2.96 \times 10^{6}$ $( \pm 0.391) \mathrm{M}^{-1}$. May be due to the size difference of In and 
$\mathrm{F}^{-}$anion, whole number stoichiometry was not observed between these two atoms. The change in enthalpy $(\Delta \mathrm{H})$ and change in entropy $(\Delta S)$ associated with this complexation are $3551( \pm 15.52) \mathrm{cal} / \mathrm{mol}$ and $40.9 \mathrm{cal} / \mathrm{mol} / \mathrm{deg}$. From Eqs. (1) and (2), the change in Gibbs free energy $(\Delta G)$ is equal to $-9250.48 \mathrm{cal} / \mathrm{mol}$ and $-9232.85 \mathrm{cal} /$ mol, respectively. The results are also tabulated in Table 3 for a quick glimpse about the interaction.

The above discussion suggests that complexation process between In and ARS is an enthalpy-driven process, whereas the interaction between $\mathrm{F}^{-}$and In-ARS complex is an entropy-driven process and leads the interaction process toward higher change in Gibbs free energy value as compared to that of the In-ARS complexation. Due to the higher $\Delta G$ value for the interaction between $\mathrm{F}^{-}$and In-ARS, the reaction moves to the forward direction resulting in interaction between In and $\mathrm{F}^{-}$anion, which in turn aids in the sensing process.

The mechanistic approach for the sensing of $\mathrm{F}^{-}$ion using ITC experiment suggests that the interaction between In-ARS complex with $\mathrm{F}^{-}$ion is endothermic in nature (positive $\Delta H$ value). According to the Le Chatelier's principle, with the increase in temperature, the reaction will favor in the direction in which excess heat can be consumed, i.e., for an endothermic reaction, the forward reaction will be preferred with the increase in temperature. In case of the interaction between InARS and $\mathrm{F}^{-}$, a regular decrease in LOD value has been obtained with the increase in temperature, while the minimum value was obtained at $313 \mathrm{~K}$.

\section{Interference study}

The interference study was carried out in presence of other halogens (viz. $\mathrm{Cl}^{-}, \mathrm{Br}^{-}$and $\mathrm{I}^{-}$) and few anions (viz. $\mathrm{SCN}^{-}, \mathrm{ClO}_{4}^{-}, \mathrm{NO}_{2}{ }^{-}, \mathrm{N}_{3}{ }^{-}$) having the same concentration to that of the $\mathrm{F}^{-}$ion. The results so obtained suggested that there was no significant interference from any of the anions toward detection of trace amount of $\mathrm{F}^{-}$ ion (Fig. 7). It was also observed that interference from cations like $\mathrm{K}^{+}, \mathrm{Mg}^{2+}, \mathrm{Ca}^{2+}, \mathrm{Cr}^{2+}, \mathrm{Mn}^{2+}, \mathrm{Fe}^{3+}, \mathrm{Co}^{2+}$, $\mathrm{Ni}^{2+}, \mathrm{Cu}^{2+}, \mathrm{Zn}^{2+}$ was negligible, except in case of $\mathrm{Fe}^{3+}$ (Fig. 8). Presence of $\mathrm{Fe}^{3+}$ showed some interference but

Table 3 Thermodynamic parameters for the interaction between In with ARS and In-ARS complex with $\mathrm{F}^{-}$ion

\begin{tabular}{|c|c|c|}
\hline \multirow[t]{2}{*}{ Thermodynamic parameters } & \multicolumn{2}{|l|}{ Interaction between } \\
\hline & In and ARS & In-ARS and $\mathrm{F}^{-}$ion \\
\hline Stoichiometry & $1: 1.15$ & $1: 1.67$ \\
\hline Association constant $\left(K_{\mathrm{a}}\right)\left(\mathrm{M}^{-1}\right)$ & $1.22 \times 10^{3}( \pm 209)$ & $2.96 \times 10^{6}( \pm 0.391)$ \\
\hline$\Delta H(\mathrm{cal} / \mathrm{mol})$ & $-4748( \pm 547.1)$ & $3551( \pm 15.52)$ \\
\hline$\Delta S(\mathrm{cal} / \mathrm{mol} / \mathrm{deg})$ & -1.80 & 40.9 \\
\hline$T(\mathrm{~K})$ & 298 & 313 \\
\hline$\Delta G(\mathrm{cal} / \mathrm{mol})$ & -4211.42 or -4192.14 & -9250.48 or -9232.85 \\
\hline
\end{tabular}

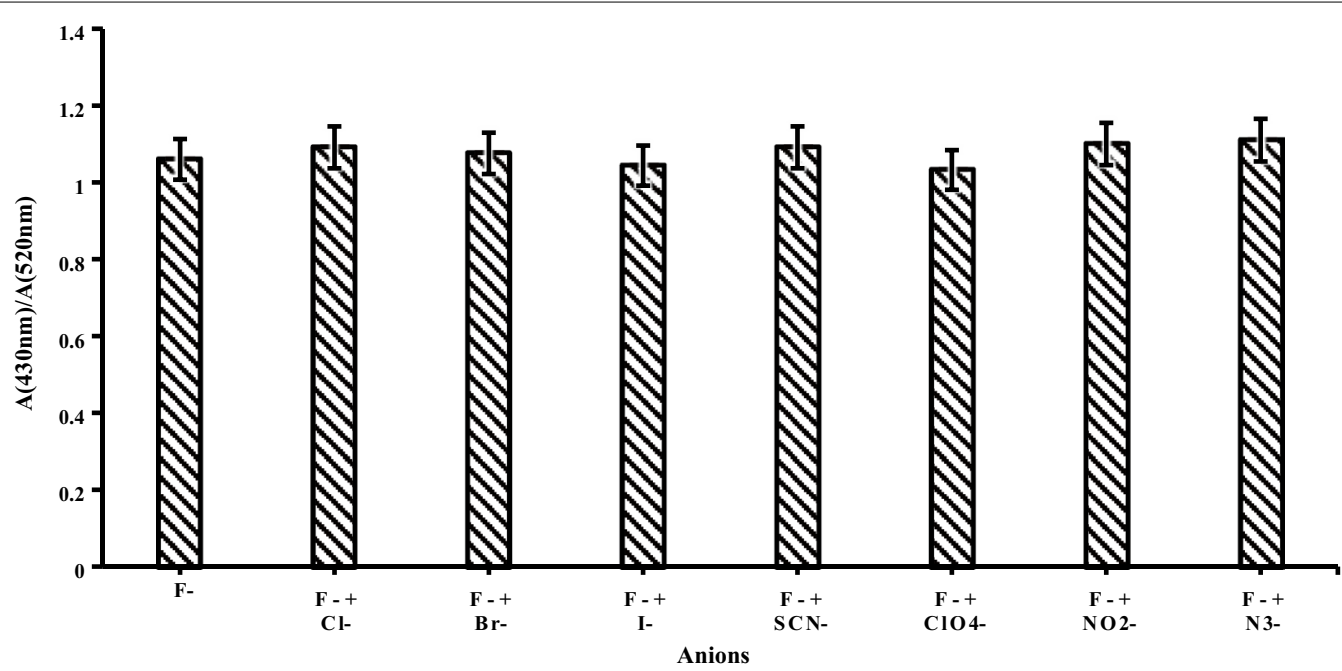

Fig. 7 Effect of interference from equimolar concentration of other halogens and anions ( $0.1 \mathrm{mM}$ each) 


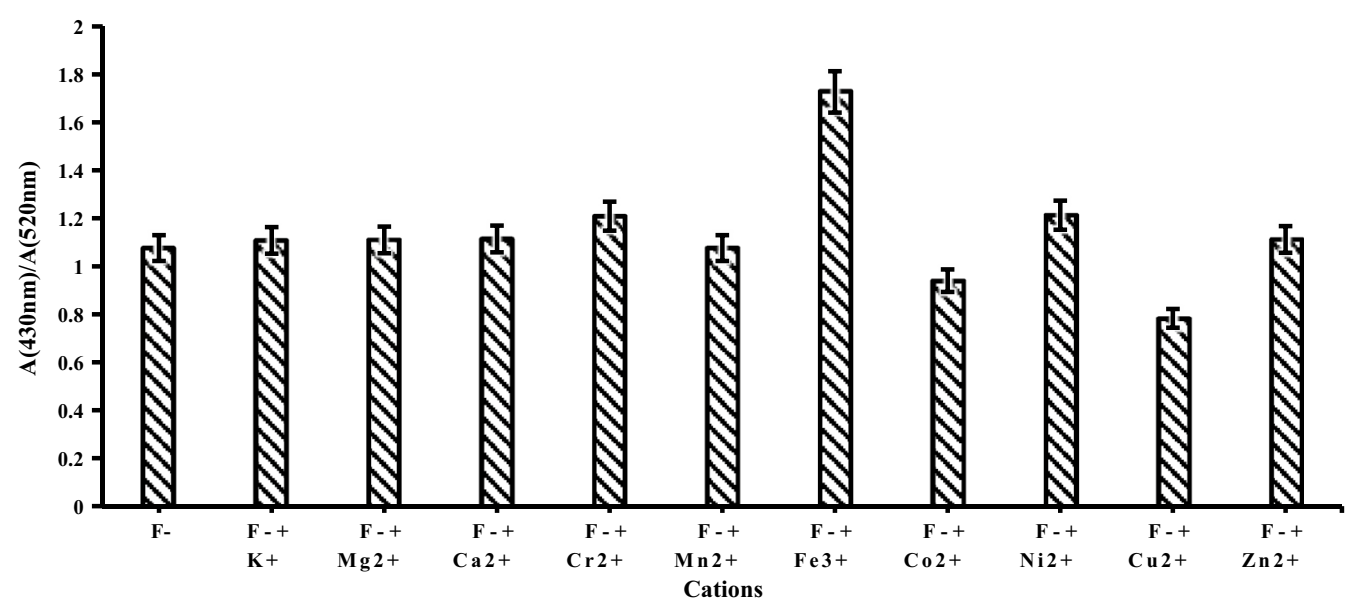

Fig. 8 Effect of interference from equimolar concentration of cations ( $0.1 \mathrm{mM}$ each)

Table 4 Analysis of natural samples

\begin{tabular}{lll}
\hline Sample & Coordinates & $\begin{array}{l}\text { Amount } \\
\text { of F } \\
\text { (mM) }\end{array}$ \\
\hline Gadkhali launch ghat (S1) & $22^{\circ} 10^{\prime} 4.70^{\prime \prime} \mathrm{N}, 88^{\circ} 47^{\prime} 16.30^{\prime \prime} \mathrm{E}$ & 0.045 \\
Jharkhali launch ghat (S2) & $22^{\circ} 01^{\prime} 6.20^{\prime \prime} \mathrm{N}, 88^{\circ} 40^{\prime} 56.10^{\prime \prime} \mathrm{E}$ & 0.049 \\
Kaikhali launch ghat (S3) & $22^{\circ} 01^{\prime} 18.42^{\prime \prime} \mathrm{N}, 88^{\circ} 37^{\prime} 3.85^{\prime \prime} \mathrm{E}$ & 0.06 \\
Matla (S4) & $21^{\circ} 39^{\prime} 10.84^{\prime \prime} \mathrm{N}, 88^{\circ} 36^{\prime} 22.50^{\prime \prime} \mathrm{E}$ & $\mathrm{BDL}$ \\
Saptamukhi (S5) & $21^{\circ} 41^{\prime} 3.15^{\prime \prime} \mathrm{N}, 88^{\circ} 21^{\prime} 6.55^{\prime \prime} \mathrm{E}$ & $\mathrm{BDL}$ \\
Farm tubewell (S6) & $23^{\circ} 40^{\prime} 36.94^{\prime \prime} \mathrm{N}, 87^{\circ} 29^{\prime} 2.56^{\prime \prime} \mathrm{E}$ & $\mathrm{BDL}$ \\
School tubewell (S7) & $23^{\circ} 53^{\prime} 57.67^{\prime \prime} \mathrm{N}, 87^{\circ} 23^{\prime} 3.39^{\prime \prime} \mathrm{E}$ & $\mathrm{BDL}$ \\
\hline
\end{tabular}

this might not obstruct the fluoride sensing mechanism. Hence, this process suggests a good selectivity toward sensing of fluoride ion in presence of other halogens and anions.

\section{Analysis of natural samples}

The developed technique was further utilized for sensing of fluoride ion in natural samples collected from different regions. Five riverine samples and two groundwater (tube well) samples were collected as mentioned earlier, and presence of fluoride was checked. The detailed result is tabulated in Table 4 and it suggested that $\sim 0.06 \mathrm{mM}$ of $\mathrm{F}^{-}$is present around Kaikhali jetty, whereas $\sim 0.05 \mathrm{mM}$ $\mathrm{F}^{-}$could be observed in the other two jetties of Gadkhali and Jharkhali. In rest of the riverine and groundwater samples, $\mathrm{F}^{-}$was below the detection limit.

\section{Conclusion}

We have successfully studied the interaction between Indium and alizarin red $S$ dye. The 1:1 stoichiometry between In and ARS was obtained from the
Benesi-Hildebrand plot at $\mathrm{pH}$ 7. This complex was then utilized for the ratiometric sensing of fluoride ion using absorption spectroscopy. The sensing experiment was carried out at three different temperatures, viz. 283, 298 and $313 \mathrm{~K}$. The lowest limit of detection (LOD), $0.040 \mathrm{mM}$ was obtained at $313 \mathrm{~K}$. It is true that there are methods which offer even lower limit of detection of $\mathrm{F}^{-}$ion. Nevertheless, this is the first time In-ARS complex was utilized for such sensing and most important is that the LOD value is much lower than the WHO prescribed limit $(0.08 \mathrm{mM})$. The interaction of In with ARS and of In-ARS complex with $\mathrm{F}^{-}$ion was studied by isothermal titration calorimetry. The ITC data suggested that the change in Gibbs free energy value and the association constant for the interaction of InARS complex with $\mathrm{F}^{-}$ion was higher than that of interaction of In with ARS. Hence, $\mathrm{F}^{-}$could easily displace ARS from the In-ARS complex, which in turn could effectively sense minute amount of $\mathrm{F}^{-}$in the solution spectroscopically. This developed technique was further applied toward natural sample to check the practicability of the technique, which was also observed to be satisfactory. Hence, the present study demonstrates a simple and cost-effective method for detection of fluoride anion in aqueous samples.

\section{Supplementary Information}

The online version contains supplementary material available at https://doi. org/10.1186/s40543-021-00308-z.

Additional file 1. Fig. S1. Interaction between In and ARS at $\mathrm{pH} 4$ medium. Fig. S2. B-H plot for the interaction between In and ARS at pH 4. Fig. S3. Interaction between $\mathrm{In}$ and ARS at pH 9 medium. Fig. S4. Interaction between In and ARS at pH 4 buffer medium. Fig. S5. Interaction between In and ARS at $\mathrm{pH} 9$ buffer medium. Fig. S6. Calibration plot for the sensing of $\mathrm{F}^{-}$at $283 \mathrm{~K}$. Fig. S7. Calibration plot for the sensing of $\mathrm{F}^{-}$at $298 \mathrm{~K}$ 


\begin{abstract}
Acknowledgements
Pritam Singh gratefully acknowledges the University Grants Commission (UGC) (Ref. No. 20/12/2015(ii)EU-V dated 24.08.2016) for providing necessary fellowship. Authors also want to thank Mr. Pratap Chandra Singh, Branch Manager, Arambagh Hatcharies Ltd, Bakreswar Branch, Birbhum District, West Bengal, for collecting the groundwater samples (Additional file 1: S6, S7) from Birbhum and Mr. Prasun Sanyal, Marine Science department, University of Calcutta, for the Matla, Saptamukhi riverine samples (Additional file 1: S4, S5) from Indian Sundarbans. Authors are also grateful to Professor Susanta Lahiri, Head, Chemical Sciences Division, Saha Institute of Nuclear Physics and Dr. Kamalika Sen, Department of Chemistry, University of Calcutta, for their valuable suggestions, help and continuous support.
\end{abstract}

\section{Authors' contributions}

NN contributed to conceptualization, investigation, methodology, writingreview and editing, and interpretation of data. PS contributed to investigation, designing and conducting experiments, original draft writing and editing, and interpretation of data. Both authors read and approved the final manuscript.

\section{Funding}

No funding.

\section{Availability of data and materials}

The data that support the findings of this study are available from the corresponding author upon reasonable request.

\section{Declarations}

\section{Competing interests}

The authors declare they have no competing interest.

\section{Author details}

'Department of Chemistry, University of Calcutta, 92, A. P. C. Road, Kolkata 700009, India. ${ }^{2}$ Saha Institute of Nuclear Physics, 1/AF, Bidhannagar, Kolkata 700064, India.

Received: 13 June 2021 Accepted: 12 November 2021

Published online: 02 December 2021

\section{References}

Agarwal M, Rai K, Shrivastav R, Dass S. Deflouridation of water using amended clay. J Clean Prod. 2003;11:439-44.

Ali S, Fakhri Y, Golbini M, Thakur SK, Alinejad A, et al. Concentration of fluoride in groundwater of India: a systematic review, meta-analysis and risk assessment. Groundw Sustain Dev. 2019;9:100224.

Barghouthi Z, Amereih S. Spectrophotometric determination of fluoride in drinking water using aluminium complexes of triphenylmethane dyes. Water SA. 2012;38:543-8.

Barghouthi Z, Amereih S. Field method for estimation of fluoride in drinking groundwater by photometric measurement of spot on aluminium quinalizarin reagent paper. Arab J Chem. 2017;10:S2919-25.

Barnett NW, Jones P, Handley HW. The use of zirconyl xylenol orange for the post-column spectroscopic detection of fluoride in ion chromatrography. Anal Lett. 1993;26:2525-9.

Bishop PL, Sansoucy G. Fluoride removal from drinking water by fluidized activated alumina adsorption. J Am Water Works Assoc. 1978;70:554-9.

Biver T, Kraiem M, Secco F, Venturini M. On the mechanism of indium(III) complex formation with metallochromic indicators. Polyhedron. 2018;156:6-13.

Bureau of Indian Standards for drinking water, (BIS 2012), IS 10500 (2012): drinking water.

Cardwell TJ, Cattrall RW, Mitri M, Hamilton IC. Flow-injection spectrophotometric determination of fluoride by using the Zirconium/Alizarin Red $\mathrm{S}$ complex. Anal Chim Acta. 1988;214:433-8.

Chaudhuri P, Naskar N, Lahiri S. Measurement of background radioactivity in surface soil of Indian Sundarban. J Radioanal Nucl Chem. 2017;311:1947-52.
Choubisa SL, Choubisa L, Choubisa DK. Endemic fluorosis in Rajasthan. Indian J Environ Health. 2001;43:177-89.

Fain VY, Zaitsev BE, Ryabov MA. Metal complexes with alizarin and alizarin red S: electronic absorption spectra and structure of ligands. Russ J Coord Chem. 2004;30:365-70.

Fawell J, Bailey K, Chilton J, Dahi E, Magara Y. Fluoride in drinking-water. IWA Publishing; 2006.

Ghatak SK, Dey D, Sen S, Sen K. Aromatic amino acids in high selectivity bismuth(III) recognition. Analyst. 2013;138:2308-14.

Gu Y, Yu L, Mou J, Wu D, Xu M, Zhou P, Ren Y. Research strategies to develop environmentally friendly marine antifouling coatings. Mar Drugs. 2020;18:371.

Guanghan L, Xiaoming L, Zhike H, Shuanglong H. Polarographic determination of fluoride using the adsorption wave of the Ce(III)-alizarin complexonefluoride complex. Talanta. 1991:38:977-9.

Hirai M, François PG. Lewis acidic stiborafluorenes for the fluorescence turn-on sensing of fluoride in drinking water at ppm concentrations. Chem Sci. 2014;5:1886-93.

Jha SK, Singh RK, Damodaran T, Mishra VK, Sharma DK, et al. Fluoride in groundwater: toxicological exposure and remedies. J Toxicol Environ Health Part B. 2013;16:52-66.

Jia Y, Li Z, Shi W. A colorimetric chemosensor for $\mathrm{F}^{-}$based on Alizarin complexone and layered double hydroxide ultrafilms. Sens Actuators B Chem. 2013;188:576-83.

Jiao Y, Zhu B, Chen J, Duan X. Fluorescent sensing of fluoride in cellular system. Theranostics. 2015;5:173.

Jin W, Wang J, Zhang X, Wang S. On the adsorption voltammetry of the lanthanum (III)-alizarin complexone-fluoride system. J Electroanal Chem Interfacial Electrochem. 1990;281:221-9.

Kubo Y, Ishida T, Minami T, James TD. Highly selective fluoride ion detection based on a fluorescent alizarin-o-aminomethylphenylboronic acid ensemble in aqueous MeOH solution. Chem Lett. 2006:35:996-7.

Leonard MA, Murray GT. Sulphonated alizarin fluorine blue: an improved reagent for the positive absorptiometric determination of the fluoride ion. Analyst. 1974;99:645-51.

Leon-Gonzalez ME, Santos-Delgado MJ, Polo-Diez LM. An improved method for the spectrophotometric determination of fluoride by addition of sodium dodecyl sulphate to the fluoride/lanthanum (III)/Alizarin fluorine blue system. Anal Chim Acta. 1985;178:331-5.

Miyazaki A, Bansho K. Indirect determination of fluoride in waters with lanthanum alizarin complexone and inductively-coupled plasma emission spectrometry. Anal Chim Acta. 1987;198:297-302.

Naskar N, Lahiri S, Mitra S, Chaudhuri P. Radiogenic quality assessment of ground and riverine water samples collected from Indian Sundarbans. Environ Res. 2020;185:109407.

Sathish RS, Kumar MR, Rao GN, Kumar KA, Janardhana C. A water-soluble fluorescent fluoride ion probe based on Alizarin Red S-Al (III) complex. Spectrochim Acta A. 2007;66:457-61.

Sen KK, Rao MA, Frizzell G, Rao A. Low-cost device for the estimation of fluoride in drinking water. Field Anal Chem Technol. 1998;2:51-8.

Shen ZL, Wang SY, Chok YK, Xu YH, Loh TP. Organoindium reagents: the preparation and application in organic synthesis. Chem Rev. 2013;113:271-401.

Srivastava B, Sen S, Sen K. Free serum sorbitol and its interaction with caffeine: a suggestive approach for plausible remediation of diabetic neuropathy. Biotechnol Appl Biochem. 2020. https://doi.org/10.1002/bab.2083.

WHO. Guidelines for drinking-water quality. Health criteria and other supporting information, vol. 2. 2nd ed. World Health Organization; 1996.

WHO. Guidelines for drinking-water quality. Recommendations, vol. 1. 3rd ed. World Health Organization; 2004.

Xu XR, Li HB, Gu JD, Paeng KJ. Determination of fluoride in water by reversedphase high-performance liquid chromatography using $\mathrm{F}^{-}-\mathrm{La}^{3+}$-alizarin complexone ternary complex. Chromatographia. 2004;59:745-7.

Yasuda SK, Lambert JL. Cellulose supported thorium-alizarin red S reagent for fluoride ion determination. Anal Chem. 1958;30:1485-9.

Zhang L, Li J, Zeng Y, Meng L, Fu C. Highly selective molecularly imprinted polymer sensor for indium detection based on recognition of In-Alizarin complexes. Electroanalysis. 2015;27:1758-65.

Zhou Y, Zhang JF, Yoon J. Fluorescence and colorimetric chemosensors for fluoride-ion detection. Chem Rev. 2014;114:5511-71. 


\section{Publisher's Note}

Springer Nature remains neutral with regard to jurisdictional claims in published maps and institutional affiliations.

Submit your manuscript to a SpringerOpen ${ }^{\circ}$ journal and benefit from:

- Convenient online submission

- Rigorous peer review

- Open access: articles freely available online

- High visibility within the field

- Retaining the copyright to your article

Submit your next manuscript at $\boldsymbol{\nabla}$ springeropen.com 